號七十四第誌雑會學類入京東

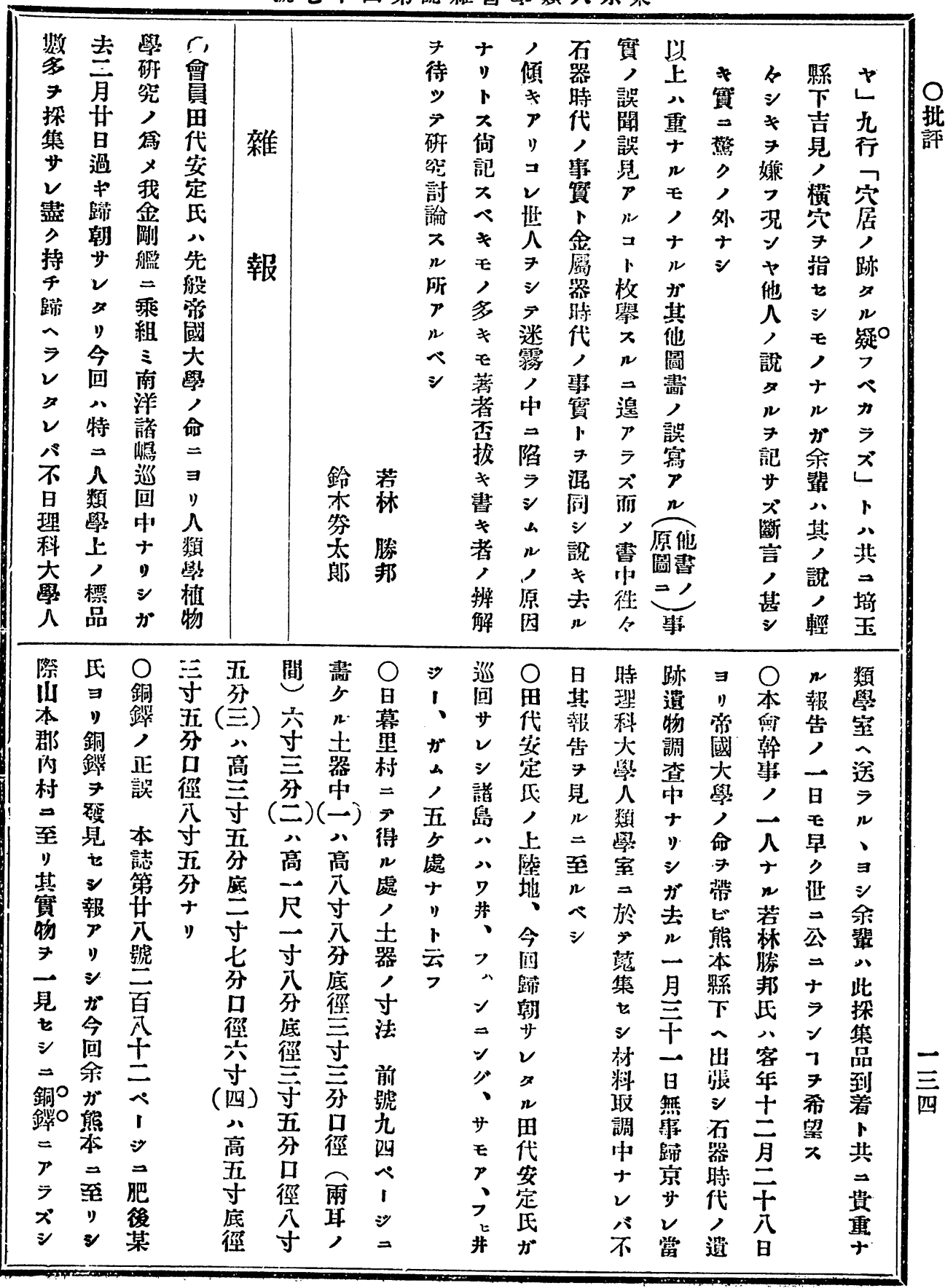




\section{月二年三十二治 明}

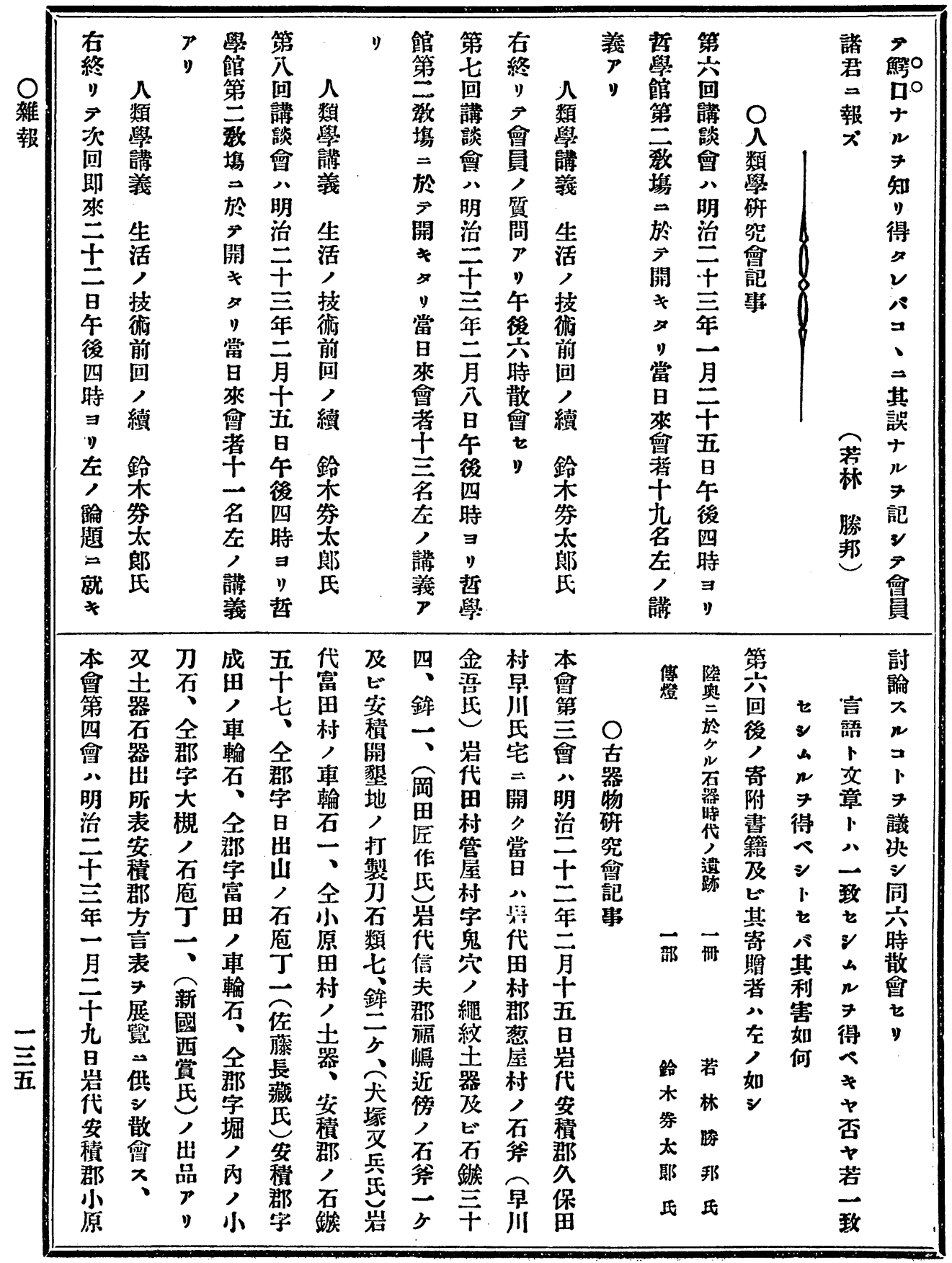

